Nowoczesne Systemy Zarządzania

Zeszyt 15 (2020), nr 1 (styczeń-marzec)

ISSN 1896-9380, s. 31-44

DOI: $10.37055 / \mathrm{nsz} / 132716$

Modern Management Systems

Volume 15 (2020), No. 1 (January-March)

ISSN 1896-9380, pp. 31-44

DOI: $10.37055 / \mathrm{nsz} / 132716$
Instytut Organizacji i Zarządzania Wydział Bezpieczeństwa, Logistyki i Zarządzania

Wojskowa Akademia Techniczna

w Warszawie

Institute of Organization and Management Faculty of Security, Logistics and Management Military University of Technology

\title{
The Concept of Gender and Legislative Support of Gender Rights Protection at the Current Stage of the Armed Forces of Ukraine Development
}

\author{
Koncepcja gender i prawne wsparcie \\ ochrony praw płci na obecnym etapie \\ rozwoju Sił Zbrojnych Ukrainy
}

\author{
Yurii Korniichuk \\ Korolov Zhytomyr Military Institute, Zhytomyr, Ukraine \\ korniy.yg@gmail.com, ORCID: 0000-0002-0699-3811 \\ Iryna Ostrovska-Buhaichuk \\ Korolov Zhytomyr Military Institute, Zhytomyr, Ukraine \\ irina-2008_84@ukr.net, ORCID: 0000-0002-9371-0348 \\ Nataliia Lazurina \\ Korolov Zhytomyr Military Institute, Zhytomyr, Ukraine \\ mail@buy-ua.com, ORCID: 0000-0001-9146-3323
}

\begin{abstract}
The article presents an analysis of the concept of gender and gender stereotypes. The difference between the concepts of gender and sex category is analyzed. The generally accepted international regulatory legal act on gender equality in the military are covered, and special attention is paid to the consideration of the main aspects of the national legislation in the aforementioned course.

Keywords: gender, gender role stereotypes, gender role norms, gender equality.

Abstrakt. Artykuł przedstawia analizę pojęcia płci i stereotypów płciowych. Analizowana jest różnica między pojęciami gender i płci biologicznej. Analizowane są również ogólnie przyjęte międzynarodowe akty prawne dotyczące równości płci w wojsku, a szczególną uwagę zwraca się na uwzględnienie głównych aspektów ustawodawstwa krajowego w wyżej wymienionym kierunku.

Słowa kluczowe: płeć, stereotypy dotyczące roli płci, normy roli płci, równość płci.
\end{abstract}




\section{Introduction}

A significant trend in the world gender policy under current conditions is to ensure equal rights for men and women in all areas of public life. Through this, in modern society women take an active part in the political, economic, social spheres of the state life, have all the opportunities to successfully self-realize in their chosen professional field of activity.

Gender policy at the international level is a relatively young political direction, but it contains the main tendencies the Ukrainian state also aims to implement. The result of this implementation was the formation of the Ukrainian concept of gender policy, which considers in its content all existing world models, as it uses the methods of different models in solving gender problems.

\section{Research results}

The multi-dimensionality of gender issues in the EU countries is due to a number of areas of public life that require thorough study and radically new approaches to fundamental principles in order to minimize gender gaps. The issue of gender equality at all levels, from women's participation in the political process of the state to proper payment for both sexes, is crucial to society. Over the past 20 years, the world has made significant progress in promoting the principle of gender equality. Precisely such progress has taken place in the armed forces, which has led to an increase in the number of women in the armies of the world's nations. This situation has contributed to the intensification of research on gender equality in the armed forces.

The military aspect of women's social issues was especially actively studied in the second half of the past century by American and Western European researchers. It was during this period that special research works appeared on the role of women in the army. The most known and competent experts in this field are M. Binkin, S. Enlow, D. Mitchell, D. Parker, M. Rastad, M. Janowitz.

As for the derivation of the term «gender», it appeared comparatively recently, in 1975, due to a clear differentiation between constitutional and sociocultural aspects in the distinction between male and female, associating them with the concepts of gender and sex category. The term «gender» refers to the specific roles, relationships, personality traits, attitudes, behaviors, and life values that society assigns to men and women.

Gender (from English gender - "sex", from the Latin genus - «sort») is a sociobiological characteristic through which the concepts of «man» and «woman», psychosocial, sociocultural roles of man and woman as personalities, as well as psychobiological features influenced by biological sex, holistic mental representation of sex, full of unique dynamic deep, cognitive and behavioral concepts of female and male, acquired by a personality as a result of gaining individual gender 
experience. That is to say, it is some social constructor that determines the social sex of a person (Sean Bern, 2004).

Unlike biological sex, gender is a set of social role self-identifications (selfdeterminations), which may coincide with or contradict purely biological features. Gender differences are formed in the process of socialization, i.e. learning the role of men and women, which occurs from the first days of birth to puberty, and after that they are formed to a lesser extent. This is influenced by family upbringing, school, interaction with other children and play activities.

A review of the opinions of various researchers on the conception of the category "gender» (Voronina, Lovtsova, Pushkaryova, Hu Doba, Hoff, Mayer) indicates that in all cases of use of this term there are four groups of characteristics: gender role (gender) stereotypes, biological sex, gender role norms and gender role identity (Zdravomyslova, Tyomkina).

Stereotypes are the usual ideas about a person who belongs to a certain group (racial, sexual, ethnic, age, and other). They are formed in our consciousness under the influence of society. The stereotype starts to work even before the mind is turned on. This leaves a specific imprint on the data that is perceived by our senses before these data reach the mind. Nothing so resists formation or criticism as a stereotype, as it leaves its imprint on the actual data at the time of their perception.

To some extent, extrinsic stimuli, especially spoken or printed, activate some part of the system of stereotypes, so that the direct impression and the previously formed thought appear in the mind at the same time. In cases where the experience contradicts the stereotype, a twofold result is possible: if an individual has already lost some flexibility or because of some significant interest it is extremely inconvenient to change his stereotypes, he can ignore this contradiction and consider it an exception, confirmed by the rule, or find some error and then forget about the event. But if he has not lost his curiosity or ability to think, then innovation is integrated into the already existing view of the world and changes it.

Gender stereotypes are generalized ideas (beliefs) formed by culture about how men and women behave. The term should be distinguished from the concept of gender role, which means a set of expected patterns of behavior (norms) for men and women. The emergence of gender stereotypes is due to the fact that the model of gender relations has historically been built in such a way that sex differences prevailed over individual and qualitative differences in the personality of man and woman.

There are psychological and social functions of gender stereotypes. The psychological functions include:

1. Cognitive function, when gender stereotypes, like all social stereotypes, save the effort of the individual in the perception of complex objects, simplifying and systematizing the knowledge obtained by the individual from the environment. In addition, gender stereotypes help to predict the future behavior of a group or a member of that group. 
2. Value-protective function associated with the establishing and support of values of the individual and group. Thus, stereotypes about male selfishness and heartlessness become the background for women to emphasize their own care and mercy. By supporting the identity and values, stereotypes help to draw clear boundaries between trusted friends and all outsiders.

One of the most common mistakes in understanding the concept of "gender" is to use it interchangeably with the concept of "sex". Associal gender does not necessarily coincide with an individual's biological sex, his or her parenting gender, or his/her passport gender, so research uses a broad understanding of gender.

According to V. Geodakyan, the term "sex" describes biological differences between people, which are determined by the genetic features of cell structure, anatomical and physiological characteristics and fertility functions. The term "gender" is a social sex, sex as a product of culture, a socio-biological characteristic that indicates the social status and socio-psychological characteristics of a person that are related to sex and sexuality, but arise in interaction with other people.

I.Kon believes that both sex and gender are systems of symbols that form a certain sequence of relations between people, their attitudes to various demonstrations of sexuality, as well as determine sociality in behavior (Kon, http: //sexology.narod. $\mathrm{ru} /$ book). Therefore, sex and gender are not complementary categories and social constructs of human sexuality. The World Health Organization (WHO) uses the term "gender" to define "socially determined roles, patterns of behavior, activities, and attributes that a society considers necessary for men and women." Gender is one of the basic characteristics of personality that determine the psychological and social development of a person. Thus, "gender" refers to artificially established differences between men and women, as opposed to the term "sex," which refers to the biological differences between males and females.

As for the understanding of the term "gender identity", it differs: awareness of the connection with the cultural definitions of masculinity and femininity (Voronina); belonging to one or another social group on the basis of sex (Tereshenkova, Radina); psychosexual development, learning social roles and forming sexual preferences (Henderson); sociopsychological phenomenon, the product and process of constructing the subject of himself and social reality with the help of constructs of masculinity and femininity (Zdravomyslova, Tyomkina); identification of oneself with a certain sex, attitude to oneself as a representative of a certain sex, mastering the corresponding forms of behavior and forming personal characteristics (Bendas); the aspect of self-consciousness, which describes a person's experience of himself as a representative of a certain sex (Kletsyna), personal awareness of its connection with the cultural definitions of masculinity and femininity (Rymarev); belonging to one or another social group on the basis of sexual character (Tereshenkova, Radina). Sometimes the concept of gender identity includes an aspect related to psychosexual development and the formation of sexual preferences (Bendas, 2006). 
However, the most common definition of gender identity is due to the fact that it is understood as a result of personal self-identification with a particular sex, attitude to himself as a representative of a particular sex, the adoption of appropriate forms of behavior and the formation of personality traits (Govorun, Kolesov, Titarenko, Romanova). For all the variety of components that can be included in the structure of gender identity, which are most often repeated, there are two components: biological sex (male/female) and masculinity/femininity as constructs of culture and internalized psychological traits (Voronina, Vorontsov, Zdravomyslova, Znakiv, Labunskaya, Lovtsova, Ozhigova, Pushkareva, Tyomkina, Hoff) (Rymarev Yu, 2006, p. 22).

Gender identity depends largely on social (historical and geographical) factors, rather than on the biological nature of a person (Alekseeva, 2006, p. 19).

There are several stages in the development of gender identity:

- the stage of formation of gender identity, which begins in the fetal period (P. Lesgaft). The scientist believes that the masculine features of femininity are laid down when a woman is expecting a child, and in the case of an unwanted pregnancy or a mismatch of expectations regarding the sex of the child, all this can give impetus to the development of gender dissent;

- The next stages of development of gender identity take place in the age of the infant, preschool age, primary school and adolescence. At each of these stages, gender identity is developed as a component of self-awareness. Analysis of psychological research on the problem of gender identity generation shows that there are several theories that explain the mechanisms of gender roles comprehension in the process of socialization, which can be combined into 3 main approaches to understanding the process of mental development (Asmolov, Obukhova).

As part of the biogenetic approach, the theory of identification of S. Freud was established, as for the sociogenetic approach, the theory of social expectations (Stockard, Johnson, Weitzman) and the theory of sex typing (Michel, Bandura) were developed; the theory of cognitive development (Kolberg, Rebecca) and the theory of gender scheme (Bem) were introduced. There are several approaches to the typology of gender identity: bipolar, androgynous, multipolar (Klyotsina, Kon, Ozhigova). The multipolar model of gender identity assumes the existence of many types of gender identity. Analysis of definitions of gender identity allows us to identify its main components: biological sex and masculinity, femininity, androgyny as psychological characteristics of the individual.

Having analyzed the concept of "gender" and its main characteristics, we can conclude that the term "gender" is a social sex, sex as a product of culture, socio biological characteristic that indicates the social status and sociopsychological characteristics of the individual, which are associated with sex and sexuality, but arise in interaction with other people. In turn, gender identity is the result of an 
active process that is accompanied by the emergence of a person's sense of continuity, identity and certainty due to belonging to a certain supra-individual whole. Forming an identity is the key to a person's psychic health.

With reference togender differences, one should take into account personal traits and individuality. Individuality is presentedby the traits of temperament, character, habits, predominant interests, in the qualities of cognitive processes, in abilities, and individual style of activity. It should be borne in mind that intersex differences in the temperament of warriors affect their service and combat training. Military with different types of temperaments do not differ in the level of capabilities of the psychic setup, and its peculiar expressions. Particular attention needs to be paid to differences in the motivational sphere of personality. This is perhaps most successful with a deep understanding of its internal structure.

Military service is substantially influenced by such needs as success and power; a sense of social significance of service, participation in solving national tasks, in proving the value of one's own personality; self-assertiveness through one's own activity; development. Still the implementation of these needs is differentdue to gender differences. The role of emotions in the management of human behavior is also important, because military service is intense and extreme compared to other activities. It is characterized by surprise, suddenness, unusual nature, the ability to destroy existing stereotypes of behavior, create negative mental states (anxiety, fear, affect, stress, or melancholia).

It is in overcoming such difficulties that the corresponding volitional qualities are formed. When we talk about various demonstrations of volitional efforts in activity, it should be noted that they are based on developed to some extent volitional qualities of the individual. An important condition for resoluteness is courage, i.e. the soldier's readiness to take optimal and justified risks. According to N. Skriabin, there are more courageous individuals among males than among females, but, in the sense of social courage, women are superior to men.

After all, monitoring one's own emotions and controlling them, especially in stressful extreme situations, raising professionally important volitional qualities is the basis and guarantee of the formation of personality temper as a set of core mental properties of the employee, which is the core of almost the entire system of professional actions as well as the structure of socially significant activity. The above-mentioned individual psychological qualities of male and female servicemen are demonstrated in different ways, representing a set of formed components of their personality.

Most female servicemen are «open» to the needs of society, and their motive to bring the greatest benefit to society is one of the first positions in their hierarchy of social values. The interests of society are a priority for the female serviceman. Women have the ability to put public interests above personal ones, they have honesty, initiative, ingenuity, stubbornness, sympathy. On the contrary, male servicemen reduce their social role in society solely to a military mission to protect the territory. They 
are characterized by the following personal qualities, which include: risk readiness, perseverance, organizational skills, self-sufficiency, and independence.

It can also be concluded that there is no purely «male» or purely «female» personality; any personality embodies the features of both femininity and masculinity. Also, analyzing the transformational processes taking place in modern society in general and their impact on the gender situation, it should be noted that the gender situation of modern society is difficult to define as homogeneous and clearly structured, it is characterized by polar gender issues, the emergence and functioning of which caused economic, political, cultural changes in transforming societies. Today, they have become particularly acute as the world intensifies the struggle for the establishment of democratic norms and principles. In this context, gender partnership (equal gender relations), gender equality are becoming increasingly important in political, religious, cultural, family, economic, labor and a number of other areas. Special attention in this direction is paid to the military sphere.

After all, currently, when our state is taking confident steps forward on the way to European integration, in the security and defense sector of Ukraine urgently raises the issue of equality of rights and opportunities for men and women, i.e. the principle of gender equality, which in the modern world is declared by the normative legal acts and national law.

Concerningthe international direction of creating a legal framework for gender equality issues in the military, we can observe that with the global rise in the ability of women to be represented in the military establishments, the need to include women in NATO has increased. Among the first steps towards the integration of women into NATO was the development of a policy of equal opportunities, combating discrimination and harassment. As far back as 1961, senior NATO female officers organized a conference to discuss the integration of women into Allied forces. In 1976, a structure such as the Committee on Women in the NATO Forces was established, which in 2009 was renamed the NATO Committee on Gender Perspectives (Martseniuk, 2016).

Gender equality in the armies of NATO Member countriesmeans equal rights and equal responsibilities for military personnel, regardless of sex. Equal conditions of military service and equal requirements must be provided for women and men, and they must be equally responsible for their own actions or inactions and their consequences. It was emphasized that NATO's gender policy extends not only to NATO Member countries, but also to Partner countries, one of which is Ukraine. Due to this, it is noted that for a long time the Armed Forces of Ukraine have been included in the sphere of interests and the gender policy distribution of the North Atlantic Alliance. The International Office of the Military Staff of the Gender Adviser (IMS GENAD) ensures proper coordination with NATO command structures and NATO Headquarters, facilitates the dialogue with Partner countries on relevant gender issues and liaises with international organizations and agencies providing the integration of gender perspectives in the military sphere. 
To provide gender policy the Alliance pays much attention to the implementation of gender education in NATO Member and Partner countries and in the development of NATO civilian and military personnelrelevant gender competencies.

NATO's gender policy focuses on the concept of "gender integration", which is defined as a strategy to achieve gender equality in the armed forces by enhancing the involvement of women and men in the effective accomplishment of assigned tasks at all levels considering the interests and experiences of both sexes.

NATO fulfils its policy on gender equality principle through the implementation of UN Security Council Resolutions on Women, Peace and Security. These Resolutions $(1325,1820,1888,1889,1960,2106,2122,2422,2467$, and 2493) recognize the disproportionate impact of military conflict on men and women, boys and girls, and call for the full and equal participation of women at all levels of conflict prevention, and protection from sexual violence.

The implementation of NATO's gender policy includes the collection and analysis of information on the specifics of ensuring the gender equality principle in the armed forces of NATO Member states and Partner countries.

But one of the most substantial documents for the involvement of women in the military is UN Security Council Resolution 1325 "Women, Peace, Security". Resolution (S/RES/1325) was adopted in 2000. UN Security Council Resolution is a document adopted on important security issues. Security Council resolutions are an official reflection of the opinion or will of the United Nations. The adoption of this resolution by the UN body, which is responsible for maintaining international peace and security under Article 24 of the UN Charter, demonstrates the governments that the UN Security Council considers it necessary to draw on the experience of women in resolving conflicts, restoring peace and protecting women from gender caused violence during conflicts.

In the Resolution the Security Council provides recommendations to both states and international organizations on the involvement of women in the resolving of military conflicts, namely:

- calls on states to ensure greater participation of women at all levels of decision-making within national, regional, and international institutions and mechanisms for conflict prevention, management and resolution, urges Member States to increase their voluntary financial, technical and material support for personnel gender training, offers Member States to include provided recommendations in national training programmes for military and civilian police, civilian peacekeeping personnel;

- appealsto the Secretary General to advance the participation of women at decision-making levels in conflict resolution and peace processes and to appoint more women as Special Representatives and Envoys for peacekeeping missions, UN field operations, especially military observers, civilians, police, human rights and humanitarian personnel; 
- the integration of a gender component into peacekeeping operations, ifit is appropriate, including efforts applied by such funds and programmes;

- give guidance to Member States on training and provide them with materials related to the protection of rights and special needs of women, as well as a significant involvement of women in all peacekeeping and peacebuilding activities;

- invokes all parties to take a gender-based approach to the negotiation and implementation of peace agreements, including: (a) the special needs of women and girls during repatriation and resettlement, as well as rehabilitation, reintegration and post-conflict reconstruction; (b) support measures to aid local peace initiatives proposed by women and local conflict resolution processes and the involvement of women in all peace negotiation mechanisms; (c) measures to ensure the protection of and respect for the human rights of women and girls, especially as regards the constitution, the electoral system, and the activities of the police and the judiciary.

The UN Security Council also calls on all parties of armed conflicts to fully adhere to international law applicable to the rights and protection of women and girls, especially if they are civilians. The important recommendations of the UN Security Councilare on the responsibility of all states for the cessation of lawlessness and the prosecution of perpetrators of genocide, crimes against humanity and war crimes, including crimes involving sexual and other forms of violence against women and girls, and thereby for the need to ensure these crimes cannot be extended to amnesty provisions, when it is possible (UN Security Council Resolution 1325 «Women, Peace, Security»).

Therefore, Security Council Resolution 1325 (2000) emphasizes the importance of changing the perception of the role of women not only as victims of conflict, but also as participants in conflict resolution and peacekeeping at the same level as men.

As for the national legislation of Ukraine, it is essentially related to the issues of ensuring gender equality and peacebuilding. Thus, Ukraine has introduced the development of a number of normative documents that indicate the need to implement international standards to ensure gender equality at various levels and spheres of human life.

First of all, equality of rights of women and men in Ukraine is guaranteed by the Basic Law of the state, which stipulates that every citizen of society, both men and women, has the integrity of socio-economic, political and personal rights and freedoms (Constitution of Ukraine, 1996, p. 141). There are no privileges or restrictions by race, color, political, religious or other beliefs, sex, ethnic or social origin, property status, place of residence, language or other characteristics.

The equality of rights of women and men is ensured by providing women with equal opportunities with men in socio-political and cultural activities, in education and training, in work and recompensing for it; special measures for labor and 
women's healthprotection, the establishment of pension benefits; creating conditions enabling women to combine work with motherhood; legal protection, material and moral support of motherhood and childhood, including the provision of paid leave and other benefits to pregnant women and mothers. These principles are traced in a number of other articles of the Constitution and regulations of Ukraine, such as the Labor Code of Ukraine, the Family Code of Ukraine, the Civil Code of Ukraine and the Criminal Code of Ukraine, laws of Ukraine on education, pensions, state assistance to families with children, labor protection, Fundamentals of Ukrainian legislation on health care and others.

In the broader context of ensuring gender equality, i.e. equal rights and opportunities for women and men, it fits into the concept of human rights. Therefore, the issue of gender equality is also considered in the context of human rights. Thus, the basis of national legislation on gender policy in Ukraine is generally accepted international legal acts, namely: the Universal Declaration of Human Rights, the UN Convention on the Elimination of All Forms of Discrimination against Women, the International Covenant on Civil and Political Rights, the International Labor Organization Convention № 156 on equal treatment and equal opportunities for working men and women, Council of Europe recommendations, final documents of the Fourth UN World Conference on Women (Beijing, 1995) "Beijing Platform for Action", UN General Assembly resolution № 1325 "Women, peace and security" etc.

Conceptual approaches to the implementation of the abovementioned norms in the legislation governing conscription and military service need special attention. According to Article 1 of the Law of Ukraine "On Ensuring Equal Rights and Opportunities for Women and Men" of September 8, 2005, gender equality is an equal legal status of women and men and equal opportunities for its implementation, which allows persons of both sexes to participate equally in all spheres ofsocial life. Thus, legislation governing conscription and military service should provide both women and men with equal opportunities to carry out their functional duties, without violating the natural rights of both sexes.

Another concept, which our country is implementing at the legislative level, is to ensure gender equality. The latter in turn includes gender sensitivity, understanding of the problems of inequality and gender discrimination in various forms and the ability to respond to them (prevent, criticize, etc.). The definition of the concept "gender discrimination" is also given in Article 1 of the Law of Ukraine "On Ensuring Equal Rights and Opportunities for Men and Women" in the following way: "sex discrimination means action or inaction expressing any distinction, exception or privilege based on sex differentiation, if they are aimed at restricting or preventing the equal recognition, application or fulfillment of human rights and freedoms for women and men". 
In order to establish the principles of preventing and resisting discrimination in Ukraine, the Law "On the Principles of Preventing and Combating Discrimination in Ukraine" was established.

This regulatory legal act enshrines the definition of discrimination and its main forms; introduction of the principle of non-discrimination in the legislation of Ukraine; establishing a prohibition of discrimination with the simultaneous definition of actions that are not considered discrimination; identification of subjects endowed with powers to prevent and resist discrimination, empowerment of the Commissioner for Human Rights of the Verkhovna Rada of Ukraine with powers to prevent and resist discrimination; introduction of anti-discrimination expertise which is mandatory for draft laws of Ukraine, acts of the President of Ukraine, other regulations developed by the Cabinet of Ministers of Ukraine, ministries, other central and local executive bodies.

Let us dwell in more detail on the basic concepts enshrined in the Law of Ukraine "On Principles of Preventing and Combating Discrimination in Ukraine." Thus, in accordance with the above law, the characteristic features of discrimination include:

- the fact of violations of rights and freedoms;

- the presence of a certain protected feature on the basis of which the distinction is made;

- lack of a legitimate, objectively justified purpose for which a distinction is made;

- non-compliance with the principle of proportionality between the purpose of the distinction and the ways to achieve it.

The discrimination can also be of different types:

- direct discrimination implies a situation in which a person and/or group of peopleby some indicators of behaviour are less favourable than another person and/or group of people in a similar situation, except when such behaviour has a legitimate, objectively justified purpose to be necessarily achieved;

- indirect discrimination denotes a situation in which the implementation or application of formally neutral legal norms, evaluation criteria, rules, requirements or practices for a person and/or group of peopleby some indicators of behaviour creates less favourable conditions or situation compared to other people and/or groups of people.

The types of discrimination can be as follow:

- oppression which means undesirable behavior for a person and/or group of people, the purpose or consequence of which is the humiliation of their human dignity by some indicators or the creation of a tense, hostile, abusive or degrading atmosphere in relation to such person or group of people;

- incitement to discrimination which implies instructions or calls for discrimination against a person and/or group of peopleby some indicators;

- assistance in discrimination which is any intentional assistance in committing acts or omissions aimed at discrimination. 
The demonstrations of gender-based violence are as follow:

- physical, sexual and psychological violence that takes place both in the family and in society, including beatings;

- sexual violence against girls;

- violence related to dowry;

- marital rape;

- female genital damage and other traditional practices that harm women;

- extramarital violence;

- exploitation-related violence;

- sexual harassment at work and in education;

- forced pregnancy;

- forced abortion;

- forced sterilization;

- women trafficking and forced prostitution;

- violence by or for the connivance of the state.

Supporting the government's actions on gender equality policy, on February 24, 2016, the Cabinet of Ministers of Ukraine approved the National Action Plan for the Implementation of the UN Security Council Resolution "Women, Peace, Security" for the period up to 2020, which includes a number of tasks, namely:

- assessing the impact of conflicts on the national human rights system, in particular on the protection, assistance and rehabilitation of victims of gender-based violence, women's participation in peacebuilding and conflict prevention;

- assessment of the impact of the crisis on the infrastructure, organization, and functioning of the service delivery system;

- coordination of the activities of the parties involved in the implementation of UN Security Council Resolution 1325;

- organization of professional training;

- expanding women's participation in peacebuilding and peacemaking, forming a culture of peace;

- raising public awareness of safe behavior during the stay in the area of the anti-terrorist operation, the settlement located on the line of contact, and in the temporarily occupied territories;

- preventing and combating violence against women;

- improving the system of protection of women and girls affected by conflicts (identification, developing of a system of assistance, informing about assistance);

- establishing a system of comprehensive assistance to victims of conflicts;

- assessing of the impact and effectiveness of the implementation of the National Action Plan by the UN Security Council Resolution 1325 "Women, Peace, Security" for the period up to 2020. 
Based on the identified tasks in the security and defense sector, the process of empowering women has begun. The inclusion of gender integration in the goals and priorities of defense reform makes it possible to better respond to the various security needs of society and the needs of the defense and security sector itself, to improve the operational capacity of the defense forces. The introduction of gender equality in military institutions means combining the experience, knowledge and interests of women and men.

Also, at the national level, the government approved the State Social Program for Equal Rights and Opportunities for Women and Men until 2021, aimed at strengthening institutional mechanisms for gender equality with an integrated approach to overcoming institutional constraints in the field of gender equality.

In 2017, the position of the Government Commissioner for Gender Policy was introduced, which helps to strengthen the coordination of the work of executive bodies for the practical implementation of the principle of gender equality in all realms of society.

The Council of Europe's Gender Equality Strategy for the period of 2018-2023 was adopted. The strategy aims to achieve the following goals:

- combating gender stereotypes and gender discrimination;

- preventing and combating violence against women;

- guaranteeing equal access for women to justice;

- ensuring equal participation of women and men in political and social decision-making processes;

- implementation of the strategy for achieving gender equality in politics and all activities;

- protection of the rights of migrants, refugees, women and girls seeking asylum.

\section{Conclusions}

Therefore, based on the above analysis, we can conclude that there is a gradual reconsidering of the role of women in society, government activities, gender stereotypes are currently changing, and the number of women who go to military service to defend the state is increasing. Statistics in Ukraine show that the growing number of women who are actively involved in military affairs, including hostilities, volunteering in eastern Ukraine to ensure conflict resolution and peace is already undeniable. Thus, according to the Main Personnel Department of the General Staff of the Armed Forces of Ukraine, there are currently 27,074 women in the army, and 949 of them are senior officers (13).

Being that the number of women in the military is significant, the issue of gender equality is particularly relevant. As a result, all possible measures are being taken at both the international and national levels to ensure gender equality in society. 
In particular, the renewal and improvement of the legal framework for gender equality fosters providing equal opportunities for men and women to implement their rights and fulfill their responsibilities, as well as to protect the interests of equal coexistence in all spheres of life.

\section{REFERENCES}

[1] Алєксеева А., Психологічна стать як чинник ста новлення особистісної ідентичності у юнацькому віці: Автореф. дис... канд. психол. наук: 19.00.07. - К., 2006. - 19 с.

[2] Бендас Т., Гендерная психология: Учебное пособие/Т. Бендас - СПб.: Питер, 2006. - 431 с.

[3] Зятьєв С.І., Медсестри і снайпери/С. І. Зятьєв // Народна армія. - 2016. - № 8. - С. 7.

[4] Кон. И.С. - http://sexology.narod.ru/book.

[5] Конституція України : закон України від 28 червня 1996 р. № 254к/96 // Відомості Верховної Ради України. - 1996. - № 30. - с. 98.

[6] Марценюк Т., Жінки у збройних силах світу та України: на шляху до інтеграції (Електронний ресурс)/T. Марценюк. - Режим доступу : povaha.org.ua/zhinky-uzbrojnyh-sylah-svitu-taukrajiny-na-shlyahu-do- intehratsiji/.

[7] Про забезпечення рівних прав та можливостей жінок і чоловіків/Закон України від від 8 вересня 2005 року № 2866 - IV [Електронний ресурс]. - Режим доступу: http://zakon. rada.gov.ua/laws/show/2866-15 - accessed on 15.06.2020.

[8] Про засади запобігання та протидії дискримінації в Україні/ Закон України від від6 вересня2012року№ 5207 IV [Електронний ресурс]. - Режим доступу: https://zakon.rada.gov. ua/laws/show/5207 - accessed on 15.06.2020.

[9] Реалізація Національного плану дій з виконання резолюції Ради Безпеки ООН 1325 “Жінки, мир, безпека": досвід іноземних країн та поради для України/ІКЖЦ, Л. Нечипоренко, М. Руденко, О. Суслова - К.: ФОП Москаленко О.М., 2016. - 82 с.

[10] Резолюція Ради Безпеки ООН 1325 «Жінки, мир, безпека»: http://www.un.org/womenwatch/ osagi/wps/\#resolution.

[11] Рымарев Ю., Личностные особенности подростков с различной гендерной идентичностью: Автореферат. дис... канд. психол. наук: 19.00.01/ Кубанский гос. ун т. - К., 2006. - 22 с.

[12] Шон Берн. Гендерная психология/Шон Берн. - СПб. : Прайм-ЕВРОЗНАК, 2004. - 320 с.

[13] https://www.mil.gov.ua/news/2019/09/17/kilkist-zhinok-u-nashomu-vijsku-za-desyat-rokivzbilshilas-u-15-raziv/. 